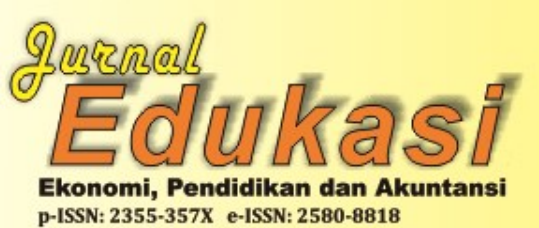

Program Studi Pendidikan Akuntansi

Fakultas Keguruan Dan Ilmu Pendidikan UNIVERSITAS GALUH CIAMIS

p-ISSN: 2355-357X e-ISSN: 2580-8818

https://jurnal.unigal.ac.id/index.php/edukasi/article/view/4324

\title{
PERAN PEREMPUAN TERHADAP PENGUATAN EKONOMI KELUARGA DI KABUPATEN CIAMIS
}

\author{
Oleh: \\ Yuyun Susanti ${ }^{1}$, Rita Patonah ${ }^{2}$ \\ Program Studi Pendidikan Akuntansi \\ Fakultas Keguruan dan Ilmu Pendidikan Universitas Galuh \\ yuyunsusanti444@gmail.com \\ Sejarah Artikel: Diterima September 2020, Disetujui Oktober 2020, Dipublikasikan November 2020
}

\section{ABSTRAK}

Penelitian ini bertujuan untuk mengetahui peran perempuan terhadap penguatan ekonomi keluarga di Kabupaten Ciamis. Metode penelitian yang digunakan pada penelitian ini adalah kualitatif. Hasil Penelitian dapat disimpulkan; 1) Peran perempuan telah berhasil melaksanakan perannya dalam meningkatkan ekonomi keluarga. Walaupun pada kodratnya perempuan bukan tulang punggung perekonomian keluarga melainkan hanya membantu kekurangan atau menambah pemasukan perekonomian keluarga, 2) Faktor-faktor yang menyebabkan perempuan melakukan pekerjaan diluar rumah yaitu; (1) membantu perekonomian keluarga dan kebutuhan rumah tangga bisa disangga berdua, (2) berusaha mandiri dan memiliki simpanan, (3) merupakan kebanggaan, karena bisa membeli barang tanpa meminta ke suami, (4) memiliki penghasilan sendiri dan kepercayaan diri, (5) memiliki kepuasan tersendiri dengan ikut andil dalam perekonomian keluarga, (6) belajar hal baru, skill dan pengetahuanmu yang selalu terasah terus, serta (7) meminimalisir perasaan bosan dengan dunia kerja.

Kata Kunci: Peran Perempuan, Penguatan Ekonomi, Keluarga

\section{ABSTRACT}

This study aims to determine the role of women in strengthening the family economy in Ciamis Regency. The research method used in this research is qualitative. The research results can be concluded; 1) The role of women has succeeded in carrying out their role in improving the family economy. Although by nature women are not the backbone of the family economy, but only help shortages or increase the income of the family economy, 2) The factors that cause women to work outside the home are; (1) helping the family economy and household needs can be supported together, (2) trying to be independent and having savings, (3) being proud, because you can buy things without asking your husband, (4) have your own income and self-confidence, (5)) have their own satisfaction by taking part in the family economy, (6) learning new things, constantly honing your skills and knowledge, and (7) minimizing feeling bored with the world of work.

Keywords: Role of Women, Economic Strengthening, Family

\section{PENDAHULUAN}

Kemiskinan menyebabkan masyarakat desa rela berkorban demi keselamatan hidup (safety life)/ bertahan hidup, dengan mempertaruhkan tenaga secara fisik untuk memperoleh keuntungan bagi tengkulak lokal dan mendapatkan upah yang tidak sesuai dengan tenaga yang dikeluarkan (Scott dalam David A Cotter, 2002). Keterbatasan pendidikan, pengetahuan, modal ,keterampilan, dan sistem nilai yang terdapat di pedesaan merupakan kendala utama masyarakat miskin dalam memperoleh akses dan kontrol terhadap sumber daya yang ada termasuk sumberdaya untuk kegiatan ekonomi di pedesaan. Salah satu modal dasar untuk pengentasan kemiskinan adalah perempuan memiliki sumber pendapatan sendiri dengan kegigihan, kesungguhan, dan keuletan rumah tangga miskin sehingga dapat terlepas dari belenggu kemiskinan. 
Eksistensi perempuan memiliki peran penting baik pada ranah domestik (keluarga) yaitu mengelola keuangan keluarga dari hasil pendapatan suami demi berlangsungnya ekonomi keluarga dan ranah publik (masyarakat), perempuan mampu mendayagunakan sumber ekonomi melalui pemanfaatan stok modal sosial yang dimilikinya dalam lingkungan sosial untuk mempertahankan bahkan meningkatkan ekonomi keluarga (Puspitasari, 2012:69).

Pengalaman kemiskinan yang berbeda antara laki-lain dan perempuan akan berdampak berbeda antara laki-laki dan perempuan yang diakibatkan oleh kemiskinan. Permasalahan kemiskinan yang dialami perempuan berasal dari budaya patriarki, metodologi, budaya tersebut bekerja melalui pendekatan dan paradigma pembangunan. Praktek pembangunan yang bersifat hegemoni dan patriarki, serta pengambilan keputusan yang hirarkis telah meminggirkan perempuan secara sistematis dalam beberapa kebijakan, program, dan lembaga yang tidak responsif gender. Pengambilan keputusan, penyusunan program dan pembuatan kebijakan, tidak mampu mengungkap dinamika kehidupan perempuan dan laki-laki secara berkeadilan. Ketimpangan gender menyebabkan ketidakberdayaan perempuan untuk akses terhadap sumber daya yang tersedia sehingga perempuan menjadi terpuruk dalam kemiskinan.
Ditinjau dari segi sosiografis perempuan Indonesia, terdapat banyak faktor yang sangat kuat menyekat peran kaum pria dan kaum perempuan dalam ranah publik. Lebih khusus lagi, jika ditilik dari sisi kemiskinan dan pembagian peran sosialnya, perempuan miskin di Indonesia cenderung memiliki kesempatan yang terbatas untuk menolong dirinya sendiri keluar dari kungkungan kemiskinan. Kondisi ini diperparah oleh kecenderungan perempuan miskin yang memegang peran ganda dalam rumah tangga. Selain bertanggung jawab terhadap urusan domestik rumah tangga, perempuan miskin juga "terpaksa" bekerja untuk menambah penghasilan. Sedangkan perempuan miskin yang menjadi penanggung jawab domestik saja, hampir dipastikan tidak memiliki assisten rumah tangga. Hal ini menyebabkan waktu mereka terkuras dalam urusan domestiknya. Karena itu mungkin perlu dipertimbangkan perlunya forum informal yang khusus untuk perempuan miskin itu sendiri.

Berdasarkan observasi yang peneliti lakukan di Kecamatan Baregbeg, aktivitas perempuan di desa-desa tersebut cukup sibuk seperti kegiatan yang dilakukan kepala rumah tangga yaitu membantu keuangan ekonomi keluarga. Dibawah ini data desa dan perusahaan atau home indutri salah satu pegawainya memanfaatkan perempuan:

Tabel 1:

Data Potensi Industri Rumahan dan Pabrik di Kecamatan Baregbeg Kabupaten Ciamis

\begin{tabular}{cll} 
No. & \multicolumn{1}{c}{ Desa } & \multicolumn{1}{c}{ Perusahaan/Home indutri } \\
\hline 1 & Baregbeg & Peternakan ayam, Budidaya jamur \\
2 & Jelat & Pabrik Joran, Pabrik Tahu, Kompeksi budidaya jamur \\
3 & Karangampel & Kerajinan Joran, Pabrik Tahu, Peternakan ayam \\
4 & Mekarjaya & Pabrik paralon \\
5 & Petirhilir & Pabrik Tahu, budidaya Jamur \\
6 & Pusakanagara & Pabrik tahu, pabrik sale pisang \\
7 & Saguling & Pabrik tempe, pabrik keripik \\
8 & Sukamaju & Peternakan ayam \\
9 & Sukamulya & Pabrik tahu \\
\hline \multicolumn{2}{l}{ Sumber: https://m.nomor.net/_kodepos.php }
\end{tabular}

Berdasarkan tabel 1 diketahui bahwa di beberapa desa aktivitas perempuan dalam memenuhi kebutuhan sehari-harii sehingga membantu ekonomi keluarga dalam menanggulangi kemiskinan khususnya desa Mekarjaya Kecamatan Baregbeg Kabupaten Ciamis.

Kemiskinan sebagai akar segala ketakberdayaan penduduk miskin telah menggugah perhatian masyarakat dunia, sehingga isu kemiskinan menjadi salah satu isu sentral dalam Millenium Development Goals atau MDGs (UNDP, 2003). Kemiskinan salah satu akar permasalahan hilangnya martabat manusia, hilangnnya keadilan, belum terciptanya masyarakat madani, tidak berjalannya demokrasi, dan terjadinya degradasi lingkungan (Faturochman, dkk., 2007). Kemiskinan merupakan isu penting yang 
perlu mendapat perhatian yang cukup besar karena masih relatif banyak jumlah penduduk yang miskin. Upaya untuk mengurangi jumlah penduduk miskin pemerintah pusat dan pemerintah daerah melalui pendanaan akan menyalurkannya kepada masyarakat. Namum demikian, upaya yang telah dilakukan oleh pemerintah belum secara signifikan dapat mengentaskan/ mengurangi jumlah kemiskinan. Selain itu, warga miskin khususnya perempuan telah disibukkan dengan urusan pemenuhan ekonomi, sehingga waktu yang digunakan untuk berpartisipasi dapat mengurangi potensi penghasilan sehari-hari. Hal ini tentu dapat diterima, karena bagaimanapun kondisi perekonomian warga miskin, khususnya perempuan, menumbuhkan pola pikir yang pragmatis. Tentu mereka akan mengutamakan pemenuhan pangan keluarga daripada perencanaan pembangunan yang bagi warga miskin tidak memberikan efek langsung terhadap perekonomian mereka. Pada dasarnya hal ini juga dapat disiasati melalui upaya penyadaran dan penyesuaian waktu dengan jam kerja warga miskin khususnya perempuan miskin itu sendiri.

\section{METODE PENELITIAN}

Penelitian yang menggunakan penelitian kualitatif bertujuan untuk memahami objek yang diteliti secara mendalam (Imam, 2013:80). Sedangkan model penelitian yang digunakan dalam penelitian ini adalah Penelitian fenomenologi dapat dimulai dengan memperhatikan dan menelaah fokus fenomena yang hendak diteliti, yang melihat berbagai aspek subjektif dari perilaku objek. Pencarian data dilakukan dengan melakukan wawancara kepada objek atau informan dalam penelitian, dan melakukan observasi langsung mengenai objek penelitian serta menginterpretasikan pengalamannya kepada orang lain.

\section{HASIL PENELITIAN DAN PEMBAHASAN}

Peran perempuan atau ibu-ibu rumah tangga di Desa Mekarjaya Kecamatan Baregbeg Kabupaten Ciamis ini bukan hanya mengurus rumah tangganya saja, yaitu mengurus anak, mengurus suami, mempersiapkan segala keperluan anak sekolah, suami bekerja, serta segala sesuatu yang berkaitan dengan rumah tangganya. Seperti yang di sampaikan oleh Ibu Elas (48 tahun) dalam wawancara pribadi dengan peneliti:
"Hidup sekarang memang sulit makanya saya bertahan hidup dengan mencari nafkah seperti ini. Untuk kebutuhan seharihari kalo dibilang cukup engga juga soalnya kebutuhan semakin banyak belum untuk keperluan anak sekolah, bayar bayar listrik, sama makan. Caroge abdi (Suami) tidak ada sejak 7 tahun yang lalu pisah belum tanggungan Ibu yang sudah tua renta. Untuk memenuhi kebutuhan setiap hari saya mengandalkan bekerja di Pabrik Paralon Sarana Mangun Lancar, sehari mendapatkan upah 40.000kadang 50.000 untuk tanggungan 4 orang".

\section{Kewajiban Pekerja Perempuan di Rumah}

Kewajiban perempuan di rumah antaralain ialah:

1. Perempuan sebagai sumber pemenuhan kebutuhan bagi anak-anaknya.

2. Perempuan sebagai teladan bagi anaknya.

3. Perempuan sebagi pemberi stimulis bagi perkembangan anaknya. Pastilah kewajiban itu menjadi keyakinan pada semua karyawan perempuan di industri rumahan primajaya plastik yang keseluruhannya adalah ibu-ibu rumah tangga, seperti tanggapan yang disampaikan oleh salah satu pekerja perempuan yaitu Ibu Enok (49) kepada penulis melalui wawancara pribadi:

"Saya bangun udah dari pagi, setelah bangunin anak suruh mandi siap-siap buata sekolah sama suami kerja, pas mereka lagi mandi saya siapin makan, mereka pada berangkan saya langsung beres-beres rumah, beli sayuran buat nanti, semua udah selesai baru saya berangkat ketempat kesini, nanti kan jam 12.00 WIB. stop dulu tuh, saya pulang masak terus balik lagi ke sini".

Darisitu dapat di katakan bahwa semua pekerja perempuan yang berkerja di Pabrik Paralon PD. Sarana Mangun Lancar sangatlah sadar dan yakin akan kewajibannya di rumah, meskipun mereka bekerja di Pabrik Paralon tetapi kewajiban mereka di rumahnya tetap jalan sekaligus menjalankan kewajiban sebagai Ibu Rumah tangga seperti halnya yang lain.

Kewajiban Pekerja Perempuan di Pabrik Paralon PD. Sarana Mangun Lancar

1. Jam Kerja

Jam kerja di Pabrik Paralon dimulai pukul 08.00 sampai dengan 15.00 WIB. Jika 
banyak pekerjaan mereka diberikan memilih jam lembur yang dihitung setiap jam sesuai kesepakatan. Pada pukul 12.00 sampai dengan 13.00 ada jam istirahat.

2. Berkerja sesuai job yang sudah ditentukan Pembagian job kerja di industri rumahan Pabrik Paralon milik Bapak Iwan ini terbilang sangat sederhana, yaitu hanya memilih bahan baku plastik, seperti bekas botol air mineral, plastik bekas makanan lalu di bersihkan dan dikeringkan sebelum diproses mesin. Penimbang plastik dan pengangkatan, selebihnya dilakukan olehpegawai tetap Bapak Iwan yang notabennya adalah laki-laki.

\section{Hak Pekerja Perempuan di Pabrik Paralon PD. Sarana Mangun Lancar}

1. Memperoleh kebebasan untuk memilih berkerja di luar rumah Kebebasan adalah hak yang dimiliki oleh setiap orang, tetapi untuk bekerja diluar rumah bagi seorang ibu rumah tangga adalah hal yang menjadi beban tersendiri, dengan berkurangnya waktu untuk keluarga tentunya menjadi dampak yang kurang baik juga untuk keluarga itu sendiri. Disinilah tanggung jawab sebagai orang tua yang menjadi penting, peran antara ibu dan ayah dalam keluarga yang menentukan keputusan hal tersebut menjadi kunci terciptanya keluarga yang harmonis, dengan tujuan untuk keaikan keuarga itu sendiri.

2. Mendapatkan perlindungan, rasa aman dan kasih sayang dari keluarga rasa aman dan perlindungan merupakan kebutuhan asasi yang dibutuhkan oleh semua manusia, rasa aman itu biasanya didapatkan ketika berada didalam rumahnya dan berada disamping suaminya, suami bagi perempuan adalah pelindung yang membuat perempuan merasa aman dan nyaman ketika berada bersamanya.

\section{Hak yang diperoleh pekerja perempuan pekerja}

1. Pendapatkan perlindungan di tempat perempuan bekerja adalah tempat dimana perempuan memberikan separuh waktu dan tenaganya untuk menghasilkan pundi-pundi uang, di PD. Sarana Mangun Lancar tempat ke dua yang rutin di singgahi selain di rumah, sama halnya seperti di rumah, di industri pun perempuan membutuhkan perlindungan yang dibutuhkanya, seperti perlindungan kesehatannya.

Untungnya di sini Bapak Iwan selaku pemilik Pabrik sadar akan hal itu, dia selalu memberikan tunjangan seperti membantu berobat bila ada beberapa tenaja kerjanya yang mengalami sakit, atau bahkan keluarga pekerja mengalami musibah.

2. Mendapatkan gaji sesuai kesepakatan, dan libur sesuai jadwal. Gaaji adalah hak yang paling utama di terima oleh semua pekerja dimana pun tempat dia berkerja, karena gaji adalah imbalan yang diberikan seoran majikan, bos, atau pemilik perusahaan atau industri terhadap karyawannya yang telah membantu melancarkan atau menjalankan usaha yang dimiliki menjadi lancar. Samahalnya dengan gaji, libur pun sedah menjadi kesepakatan awal sebelum semua karyawan memulai kerjannya, karena libur sesuai jadwal yang ditentukan mermaksut untuk memberikan kebebasan kepada pegawai atau pekerja dihari yang sudah ditentukan.

\section{Peran Perempuan di Pabrik Paralon PD. Sarana Mangun Lancar}

Salah satu contohnya adalah Ibu Rohana 35 tahun beliau adalah seorang istri dari suami yang hanya seorang pedagang buah hasil kebun sendiri yang ditambah buah hasil berbelanja dari pasar dan beberapa buah titipan tetangga yang penghasilannya tidak menentu setiap harinya, Ibu Rohana bekerja sebagai pengepack plastik di Pabrik Paralon rumahan milik Bapak Iwan tanpa sedikitpun melalaikan tugasnya sebagai ibu rumah tangga. Sama dengan Ibu rohana Ibu Ela 29 tahun pun pekerja perempuan yang berkerja di industri rumahan milik Bapak Iwan ini, beliau juga seorang istri dari seorang suami yang berkerja sebagai karyawan took yang telah memiliki 1 orang putri yang berusia 5 tahun. Ibu Rohanah maupun Ibu Ela samasama seorang ibu rumah tangga yang memiliki kewajiban ganda antara mengurus rumah tangga seperti menyiapkan keperluan anak sekolah dan suami bekerja ditambah lagi mereka harus mencari tabahan nafkah untuk mennutupi pengeluaran ekonomi yang semakin banyak dan mahal. Bukan hal yang mudah untuk melakuakan keseluruhan hal tersebut secara bersamaan dibutuhkan tenaga dan semangat yang sangat kuat untuk menopang semua itu, 
"kata orang sunda mah yaa biar dapur tetap ngebul, kan anak juga udah mulai mau masuk TK (Taman Kanak-kanak), lagian juga klo di rumah terus iseng juga kalu semua kerjaan udah di kerjain terus ngga ngapa-ngapain lagi, yaa mending kaya gini juga".

Hanya itu keinginan yang diinginkan oleh salah satu pekerja perempuan, mungkin itu adalah keinginan yang diharapkan oleh semua pekerja perempuan, untuk memperbaiki pendidikan anak agar mereka kelak menjadi lebih baik lagi dan keluarga mereka tidak kelaparan. Peran perempuan Pekerja, bekerja baik sebagai ibu rumah tangga ataupun sebagai bread winer (pencari nafkah) disamping suaminya. Perempuan yang memiliki peran ganda sebagai seorang perempuan telah mereka terima sebagai kodrat perempuan. Karena tanpa bantuan perempuan suami tidak dapat memenuhi kebutuhan keluarga. Kemiskinan yang melanda keluarga menyebabkan perempuan tidak dapat menyerahkan kelangsungan hidup keluarga mereka kepada suami mereka, perempuan juga harus membantu segala sesuatu yang dilakukan oleh suami untuk tetap melanjutkan kelangsungan hidup keluarga mereka.

\section{Harapan Terhadap Pekerja Perempuan di} Pabrik Paralon PD. Sarana Mangun Lancar

1. Harapan keluarga terhadap pekerja perempuan di Pabrik Paralon PD. Sarana Mangun Lancar

a) Tetap menjadi teladan keluarga.

Setiap anak selalu berkaca pada orang tuanya, jika orang tua bersifat buruk pasti anak juga akan bersifat buruk, maka dari itu anak akan selalu meneladani orang tuannya. Seperti halnya jika anak melihat orang tua mereka sebagai orang yang pekerja keras maka anak pun akan melakukan hal yang sama untuk dirinya dikemudian harinya.

b) Tetap selalu ada saat dibutuhkan.

Tidak dapat dipungkiri bahwa semua anak pasti membutuhkan orang tuanya, maka sebagai orang tua haruslah sadar akan masalah itu dan tidak memperioritaskan segala kegiatan diluar rumah, melainkan keluarga yang diutamakan. Jika hubungan antara orang tua dan anak menjadi jauh atau dalam artian anak tidak menganggap orang tuannya sebagai sesuatu bisa menyelesaikan permasalahan yang mereka sengan hadapi, sudah pasti sang anak akan salah dalam mengambil langkah.

c) Bisa menjadi pendengar yang baik bagi keluarga. Orang tua harus menjadi pendengan anak yang baik, sehingga anak dapat terbuka dengan orang tuannya, karena terdapat sebagian anak yang tertutup dah hanya terbuka oleh orang-orang terdekatnya. Peran orang tua di rumah lah yang harus mengambil alih dalam hal ini, dan orang tua juga harus bisa memberikan solusi terbaik untuk setiap masalah yang anak hadapi.

d) Yang menentukan harapan anak (supaya menjadi yang lebih baik). Setiap orang mempunyai mimpi dan cita-cita, terutama anak, sebagai orang tua yang baik haruslah mendukun setiap keinginan anak, jika itu baik buat dirinya maka orang tua haruslah mendukungnya dan jika itu tidak baik maka orang tua harus bersikap tegas dan tidak memaksakan kehendak, karena akan berujung yang tidak baik.

e) Tetap memberikan kasihsayang dan pengawasan. Kasih sayang sangat lah penting dalam membesarkan anak, tanpa kasih sayang tidak akan tumbuh menjadi anak yang memiliki kasih sayang pula, maka dari itu sebagai orang tua yang bisa dibilang cukup sibuk karena berperan ganda janganlah lupa untuk memberikan perhatian dan kasih sayang kepada anak.

2. Harapan Indusrti Pabrik Paralon PD. Sarana Mangun Lancar

a) Tetap pada totalitas dan loyalitas terhadap pekerjaan dan industri. Tetap totalitas dan loyalitas itu lah harapan yang di miliki oleh Bapak Iwan selaku manajemen perusahaan Industri, karena beliau tidak akan pernah bisa untuk menjalankan semua kegiatan yang di lakukan di Industri tanpa bantuan dari tenaga pekerja perempuannya. Maka dari itu Bapak Iwan selaku pemilik menetapkan sistem kekeluargaan dalam Industri yang dia jalankan ini, agar para pekerja perempuan yang berkerja dengan beliau tidak merasa tertekan dalam menjalankan pekerjaannya. Selain itu manajemen perusahaan memberikan tanggungjawab yang jujur dan transfaran 
pengelolaan perusahaan supaya pegawai tidak merasa dibohongi dengan kinerja pengelolaan keuangan perusahaan. Informasi yang disajikan pada pelaporan keuangan merupakan tanggung jawab manajemen. Manajemen menyajikan informasi sesuai dengan keadaan yang ada. Namun, pada beberapa entitas internasional pelaporan keuangan tidak hanya dibuat oleh manajemen. Peran fungsi audit internal menjadi lebih diperluas untuk meningkatkan kualitas pelaporan keuangan yang awalnya hanya tanggung jawab manajemen. (Suherman: 2017)

b) Menjalankan etos kerja perusahaan. Etos kerja yang dimaksud Bapak Iwan ialah semangat untuk menjalankan pekerjaan yang sudah diberikan, karena menurut beliau tampa semangat tidak akan tercapai segala sesuatu yang diinginkan, seperti yang penulis kutip dari pembicaraan beliau:

"saya memperlakukan pegawai seperti keluarga sendiri, biarin aja mereka kerjanya sambil ketawa-ketawa, sambil ngerumpi-ngerumpi, saya mah ga pernah marah, yang penting kerjaan mereka lancar, lagi juga mereka kerja sambil ngerumpi-ngerumpi gitu kerjaan mereka tetep selesai juga ko, apalagi kan adat orang Ciamis senang Humor (canda) jadi buat apa marah, malahan saya sering ikutan bercanda-bercanda sama mereka".

\section{Hasil dan Manfaat yang Diperoleh Pekerja Perempuan}

Bentuk serta sistem yang dibuat oleh Bapak Iwan selaku pemilik industr PD. Sarana Mangun Lancar dengan merekrut tenaga kerga perempuan sangatlah banyak manfaat dan keuntungan yang diperoleh oleh perusahaan dan tenaga kerja itu sendiri, tidak ada alasan tertentu yang ada di pikiran Bapak Iwan selain perempuan lebih apik dalam menjalankan pekerjaan bibandingkan dengan laki-laki.

1) Hasil yang Diperoleh Pekerja Perempuan. Berdasarkan informasi yang dihasilkan oleh penulis melalui wawancara pribadi dengan salah satu pekerja perempuan di industri plastik PD. Sarana Mangun Lancar rumahan tersebut yaitu Ibu Rohana tahun ialah:

"disini kan kita di bayar perminggu, yaa lumayan dah buat belanja sayur setiap hari sama jajan anak klo ada sisa yaa nabung- nabung dah buat nambahin bayar listrik, ke dapur jadi gajih suami buat bayaran sekolah anak dah".

Selain itu di tambahkan lagi oleh Ibu Omah 34 tahun, beliau menjelaskan sebagai berikut:

"saya tinggal di Desa Mekarsari Desa mekarjaya dari sini jalan kaki dekat yaa kalau duit mah pasti dapet, saya sama suami kan bisa ngeredit motor juga kan dari hasil sini, biar dikit kan juga yang penting nambahin, daripada ngutangngutang sama orang kan mendingan kaya gini”.

Dapat penulis katakan bahwa selama para pekerja perempuan itu tetap aktif bekerja maka sedikit demi sedikit beban kebutuhan hidup mereka dapat teratasi dan bisa meningkatkan perekonomian keluarga mereka masing-masing.

2) Manfaat yang Diperoleh Pekerja Perempuan. Berdasarkan informasi dan observasi yang dihasilkan oleh penulis melalui wawancara pribadi dengan salah satu pekerja perempuan dan pengamatan lapangan di industri plastik rumahan tersebut yaitu Ibu Irma 29 tahun ialah:

"Disini mah yaa gitu dah, isinya neneknenek doyan ngoceh semua, jadi enak ga sepi, rame, daripada Cuma di rumah nonton tv, tidur-tiduran ga jelas nunggu suami pulang, yang penting kan udah masak buat siang suami makan sama anak".

Selain itu ditambahkan juga oleh Ibu Yeni 38 tahun sebagai berikut:

"Resep aja saya mah di sini, dari pada di rumah jadi ga ketinggalan informasi klo ada apa-apa di dini, kalau ada yang ngawinin apa nyunatin kita bisa tau dari sini, tau harga sayur naik apa turun juga kan saya mah dari sini, lah saya kan jarang nonton t $v$ ".

Mereka tidak ada yang merasa terbuang waktunya untuk keluarga dan tetap bisa menghasilkan dan membantu perekonomian keluarga mereka, dan nereka pun sangat senang dan terbiasa dalam nenjalankan nya. 


\section{SIMPULAN DAN SARAN Simpulan}

Berdasarkan hasil observasi, wawancara, dan dokumentasi dalam mencari hasil yang dibutuhkan oleh peneliti sebagai mana yang telah terurai pada bab-bab sebelumya yaitu tentang "Peran Perempuan Terhadap Penguatan Ekonomi Keluarga" dapat peneliti simpulkan sebagai berikut;

1. Peran perempuan atau ibu-ibu rumah tangga yang bekerja telah berhasil melaksanakan perannya dalam meningkatkan ekonomi keluarga. Walaupun pada kodratnya perempuan bukan berarti menjadi ujung tombak perekonomian keluarga hanya membantu kekurangan penambahan pemasukan keuangan perekonomian keluarga, untuk perempuan atau ibu rumah tangga yang bekerja di pabrik paralon PD. Sarana Mangun Lancar ini sangat lah berperan dalam perekonomian keluarga dengan upah atau gaji yang mereka dapatkan dan hasilnya tidak sebanding dengan resiko, usaha, maupun tenaga nya dengan berperan dirumah maupun diluar.

2. Faktor-faktor tertentu (pendukung dan penghambat) yang menyebabkan perempuan atau ibu-ibu rumah tangga melakukan pekerjaan diluar rumah yaitu; Faktor-faktor yang menyebabkan perempuan melakukan pekerjaan diluar rumah yaitu; (1) dapat membantu perekonomian keluarga dan kebutuhan rumah tangga bisa disangga berdua, (2) berusaha mandiri dan memiliki simpanan, (3) merupakan kebanggaan, karena bisa membeli barang tanpa meminta ke suami, (4) memiliki penghasilan sendiri dan kepercayaan diri, (5) memiliki kepuasan tersendiri dengan ikut andil dalam perekonomian keluarga, (6) belajar hal baru, skill dan pengetahuanmu yang selalu terasah terus, serta (7) meminimalisir perasaan bosan dengan dunia kerja.

\section{Saran}

Berdasarkan informasi yang peneliti dapatkan maka peneliti memberikan saran:

1. Untuk para perkerja perempuan di industri untuk lebih mengutamakan keluarga yang dia miliki, karena keluarga adalah segalanya, dibandingkan dengan apapun itu, selain itu persiapkanlah tabungan untuk pendidikan anak walau berapapun penghasilan yang diterima.
2. Untuk pabrik paralon PD. Sarana Mangun Lancar, hendaknya untuk memperbanyak dan memperluas jaringan untuk memasarkan prodak yang telah dihasilkan, agar menjadi lebih maju lagi dan memperkerjakan tenaga kerja perempuan lebih banyak lagi, karena semakin banyak permintaan maka harus banyak juga produksinya, untuk menghasilkan produksi yang lebih banyak maka diperlukan tenaga kerja yang banyak pula, semakin banyak keluarga yang beban ekonominya berkurang karena para ibuibu rumah tangganya membantu perekonomian keluarganya.

\section{DAFTAR PUSTAKA}

Cotter, David A. (2002). Poor People in Poor Places: Local Opportunity Structures and Household Poverty, Rural Sociology; Dec 2002; 64,4; Agriculture Journals, p.534

Faturochman, dkk. 2007. Membangun Gerakan. oleh IGWM Yasa

Imam, Gunawan. (2013) Metode Penelitian Kualitatif: Teori dan Praktik. Jakarta, PT Bumi Aksara.

Puspitasari, Dewi Cahyani. (2012). Modal Sosial Perempuan Dalam Peran Penguatan Ekonomi Keluarga; Yogyakarta: Jurnal Pemikiran Sosiologi; p.69 Vol 1, No 2 (2012)Tersedia pada https://jurnal.ugm.ac.id/jps/article/vi ew/23445/15445 diakses Tgl 03 Februari 2020, pukul 09.00 WIB)

Suherman A, \& Susanti Y. Pengaruh Audit Internal Terhadap Kualitas Pelaporan Keuangan. Ciamis: Edukasi (Ekonomi, Pendidikan dan Akuntansi). e-ISSN: 2580-8818 Vol. $5 \quad$ No. 2 2017. dalam https://jurnal.unigal.ac.id/index.php ledukasi/article/view/957 
